\title{
THE ESTIMATION OF TOTAL NITROGEN USING THE CONWAY MICRO-DIFFUSION CELL
}

\author{
BY \\ EILEEN I. SHORT \\ From the Wellcome Research Laboratories, Biological Division, Beckenham, Kent
}

(RECEIVED FOR PUBLICATION JUNE 3, 1953)

The use of the microdiffusion unit for the determination of blood urea has been described by Conway and O'Malley (1942). Recovery of urea added to blood when estimated by this method is precisely quantitative as compared with a 98 to $99 \%$ recovery given by the aeration method (Kay and Sheehan, 1934). The method has been found very useful for routine laboratory determinations, especially when dealing with large numbers of samples.

Conway (1939a) has also described a method for determining total nitrogen, using the diffusion cell to estimate the ammonia after digestion by the usual Kjeldahl technique. A modification of the method so that the same reagents as those used for blood urea estimation can be employed is described. The method is of considerable value, especially when only small amounts of sample are available or large numbers of estimations have to be performed, since distillation is avoided and all titrations may be carried out together, if necessary on the day after setting up the units.

\section{Experimental}

Reagents.-The following are required :

Potassium sulphate, analytical reagent.

Sulphuric acid, concentrated, analytical reagent.

Copper sulphate, saturated solution.

Selenium dioxide, $0.06 \%(\mathrm{w} / \mathrm{v})$ aqueous solution.

Sodium hydroxide, $40 \%(\mathrm{w} / \mathrm{v})$ aqueous solution.

Potassium metaborate, saturated aqueous solution.

Tashiro's Indicator.-Methylene blue solution in alcohol, $5.0 \mathrm{ml}$. of $0.1 \%(\mathrm{w} / \mathrm{v})$, is added to $200 \mathrm{ml}$. of $0.1 \%(\mathrm{w} / \mathrm{v})$ alcoholic solution in methyl red.

Boric Acid Absorbent.-Boric acid, 5.0 g., is dissolved in distilled water, $200 \mathrm{ml}$. absolute alcohol and
$10 \mathrm{ml}$. Tashiro's indicator added, and the volume adjusted to $1 \mathrm{l}$. with distilled water.

Hydrochloric acid, 0.02 normal.

Digestion.-For quantities up to $0.2 \mathrm{ml}$. the sample is digested in a small Kjeldahl flask prepared from a $12.5 \times 1.5 \mathrm{~cm}$. test-tube with a bulb, $2.5 \mathrm{~cm}$. in diameter, blown in the bottom. The sample is mixed with $0.5 \mathrm{~g}$. potassium sulphate, $0.5 \mathrm{ml}$. concentrated sulphuric acid, and $0.03 \mathrm{ml}$. copper sulphate. The mixture is heated gently for five minutes, allowed to cool somewhat, and $0.3 \mathrm{ml}$. selenium dioxide added. The heating is then continued so that the mixture boils gently for one hour, care being taken, especially in the early stages, to avoid loss by spitting. If these conditions are carefully observed digestion is complete in one hour. After cooling, the mixture is washed into a 10-ml. volumetric flask with distilled water, $0.375 \mathrm{ml}$. sodium hydroxide added to neutralize the bulk of the acid, and the volume adjusted to $10 \mathrm{ml}$.

For quantities of $0.5 \mathrm{ml}$. or more, the digestion is carried out in a 50-ml. Kjeldahl incinerating flask and 10 times the amounts of reagents are used. The mixture is diluted in a $50-\mathrm{ml}$. volumetric flask, using $3.75 \mathrm{ml}$. of sodium hydroxide to neutralize most of the acid before adjusting to volume.

Estimation of the Ammonium Sulphate.-Boric acid, indicator absorbent, $2.0 \mathrm{ml}$., is placed in the centre compartment of a clean Conway diffusion unit and $0.5 \mathrm{ml}$. or $1.0 \mathrm{ml}$. of the solution for estimation carefully run into the outer compartment. The lid is thoroughly coated with white soft paraffin and placed on the dish, leaving a small aperture to allow $1.0 \mathrm{ml}$. of potassium metaborate to be introduced into the outer chamber. The aperture is closed immediately and the liquids in the outer -compartment mixed by gentle rotation, care being taken not to splash the liquid from one chamber to the other. The minimum time for complete absorption of the ammonia is two hours, and titration may be carried out at any time after this period. If desired, the units may be left overnight.

The amount of ammonia absorbed is estimated by titration with 0.02 normal hydrochloric acid, the indi- 
TABLE I

ESTIMATION OF THE NITROGEN CONTENT OF A SOLUTION OF UREA

\begin{tabular}{|c|c|c|c|}
\hline \multicolumn{3}{|c|}{ Quantities } & \multirow{2}{*}{$\begin{array}{c}\text { Concentration } \\
\mathrm{N}_{2} \text { Found } \\
(\%)\end{array}$} \\
\hline $\begin{array}{l}\text { Volume } \\
\text { Digested } \\
\text { (ml.) }\end{array}$ & $\begin{array}{l}\text { Adjusted Volume } \\
\text { after Digestion } \\
\text { (ml.) }\end{array}$ & $\begin{array}{l}\text { Volume for } \\
\text { Titration } \\
(\mathrm{ml} .)\end{array}$ & \\
\hline $\begin{array}{c}\text { Micro-method } \\
0.05 \\
0.10 \\
0.20 \\
0.50\end{array}$ & $\begin{array}{l}10 \cdot 0 \\
10 \cdot 0 \\
10 \cdot 0 \\
25 \cdot 0\end{array}$ & $\begin{array}{l}1 \cdot 0 \\
1 \cdot 0 \\
0 \cdot 5 \\
0 \cdot 5\end{array}$ & $\begin{array}{l}1 \cdot 168 \pm 0.004 \\
1 \cdot 154=0.002 \\
1 \cdot 148=0.001 \\
1 \cdot 157 \pm 0.002\end{array}$ \\
\hline & \multicolumn{2}{|c|}{$\begin{array}{l}\text { Overall mean } \\
\% \text { recovery }\end{array}$} & $\begin{array}{c}1 \cdot 157=0.002 \\
99 \cdot 8\end{array}$ \\
\hline $\begin{array}{c}\text { Macro-method } \\
0 \cdot 5 \\
1 \cdot 0 \\
2 \cdot 0 \\
5 \cdot 0\end{array}$ & $\begin{array}{r}50 \cdot 0 \\
100 \cdot 0 \\
100 \cdot 0 \\
500 \cdot 0\end{array}$ & $\begin{array}{l}1 \cdot 0 \\
1 \cdot 0 \\
1 \cdot 0 \\
1 \cdot 0\end{array}$ & $\begin{array}{l}1 \cdot 152=0.002 \\
1 \cdot 156=0.002 \\
1 \cdot 149=0.006 \\
1 \cdot 157 \pm 0.002\end{array}$ \\
\hline \multicolumn{3}{|c|}{$\begin{array}{l}\text { Overall mean } \\
\% \text { recovery }\end{array}$} & $\begin{array}{c}1 \cdot 154=0.002 \\
99 \cdot 5\end{array}$ \\
\hline
\end{tabular}

The results are the mean of four determinations \pm S.E. Urea solution is equivalent to $1 \cdot 16 \%$ nitrogen.

cator change being from green to pink, and titration is continued to a faint but definite pink. An "agla " microsyringe (Trevan, 1925) which will deliver 0.001 $\mathrm{ml}$. with an accuracy of $\pm 0.00005 \mathrm{ml}$. is used for the titration. A glass tube, bent at right angles with the end drawn out to a point, is sealed on to the nozzle of the syringe. The point is allowed to dip just below the surface of the liquid during the titration and the solutions are mixed with a fine glass rod. The micrometer screw attached to the syringe may be manipulated by hand, but it is convenient to accelerate the initial stages of the titration by driving the screw by means of a low-voltage induction motor. The quantities of sample and the dilution of the product should be adjusted to give a titration figure of $0.4 \mathrm{ml}$. to $0.5 \mathrm{ml}$.
It is important that the microdiffusion units should be thoroughly clean, and the procedure described by Conway (1939b) must be carefully followed.

\section{Results}

The recoveries from a series of determinations of a solution of urea using varying quantities of sample are given in Table I. Comparison of the results with the micro- and macro-method shows that the recovery is equally satisfactory by both methods and with all the amounts of solutions used, except for the estimation using $0.05 \mathrm{ml}$. of sample, which gave a uniformly high result, although the difference is barely significant.

The results of analysis of samples of serum and urine from two dogs are shown in Tables II and III. The samples were estimated alone and after the addition of urea solution equivalent to an additional nitrogen concentration of $1.16 \%$.

In serum the results were equally satisfactory with all quantities taken for the estimation, and overall recoveries of $100.4 \%$ and $98.9 \%$ were obtained for the two samples with standard errors for a single determination of \pm 0.22 and \pm 0.26 respectively.

There was somewhat greater variation in the individual determinations in the case of the urine estimations (Table III), the overall mean recoveries being $98.8 \%$ and $101.2 \%$ with standard errors for a single determination of \pm 0.34 and \pm 0.52 .

In both serum and urine estimations satisfactory results are obtained when only $0.05 \mathrm{ml}$. and $0.5 \mathrm{ml}$. of sample respectively is used, clearly illustrating the value of the method when only small amounts of material are available.

TABLE II

ESTIMATION OF THE NITROGEN CONTENT OF SAMPLES OF SERUM AND URINE AND THE RECOVERY OF NITROGEN ADDED TO SERUM AND URINE

\begin{tabular}{|c|c|c|c|c|c|c|c|c|}
\hline \multicolumn{3}{|c|}{ Quantities } & \multicolumn{3}{|c|}{ Sample 1} & \multicolumn{3}{|c|}{ Sample 2} \\
\hline \multirow{2}{*}{$\begin{array}{l}\text { Volume } \\
\text { Digested } \\
\text { (ml.) }\end{array}$} & \multirow{2}{*}{$\begin{array}{c}\text { Adjusted } \\
\text { Volume after } \\
\text { Digestion } \\
\text { (ml.) }\end{array}$} & \multirow{2}{*}{$\begin{array}{l}\text { Volume for } \\
\text { Titration } \\
\text { (ml.) }\end{array}$} & \multirow[b]{2}{*}{$\begin{array}{l}\text { Concentration } \\
\mathrm{N}_{2}(\%)\end{array}$} & \multicolumn{2}{|c|}{ Sample $+1 \cdot 16 \% \mathrm{~N}_{2}$} & \multirow{2}{*}{$\begin{array}{c}\text { Concentration } \\
\mathrm{N}_{2}(\%)\end{array}$} & \multicolumn{2}{|c|}{ Sample $+1 \cdot 16 \% \mathrm{~N}_{2}$} \\
\hline & & & & $\begin{array}{l}\text { Total } N_{2} \\
\text { Found }(\%)\end{array}$ & $\begin{array}{c}\text { Added } \mathrm{N}_{2} \\
(\% \text { Recovery })\end{array}$ & & $\begin{array}{l}\text { Total } \mathbf{N}_{2} \\
\text { Found }(\%)\end{array}$ & $\begin{array}{c}\text { Added } \mathrm{N}_{2} \\
(\% \text { Recovery) }\end{array}$ \\
\hline \multirow[t]{2}{*}{$\begin{array}{l}0 \cdot 05 \\
0 \cdot 10 \\
0 \cdot 20 \\
0 \cdot 50\end{array}$} & $\begin{array}{c}\text { Serum } \\
10.0 \\
10.0 \\
10.0 \\
10.0\end{array}$ & $\begin{array}{l}1 \cdot 0 \\
1 \cdot 0 \\
0 \cdot 5 \\
0 \cdot 5\end{array}$ & $\begin{array}{l}0.821 \pm 0.007 \\
0.827 \pm 0.003 \\
0.825 \pm 0.003 \\
0.827 \pm 0.002\end{array}$ & $\begin{array}{l}1.993 \pm 0.005 \\
1.982 \pm 0.003 \\
1.996 \pm 0.002 \\
1.990 \pm 0.005\end{array}$ & $\begin{array}{r}100 \cdot 9 \\
99 \cdot 5 \\
100 \cdot 9 \\
100 \cdot 2\end{array}$ & $\begin{array}{l}0.849 \pm 0.003 \\
0.848 \pm 0.004 \\
0.854 \pm 0.005 \\
0.860 \pm 0.005\end{array}$ & $\begin{array}{l}1.995 \pm 0.004 \\
1.995 \pm 0.004 \\
2.000 \pm 0.004 \\
2.004 \pm 0.003\end{array}$ & $\begin{array}{l}98 \cdot 8 \\
98 \cdot 9 \\
98 \cdot 8 \\
98 \cdot 6\end{array}$ \\
\hline & \multicolumn{2}{|c|}{ Overall means } & $0.825 \pm 0.002$ & $1.990 \pm 0.002$ & $100 \cdot 4$ & $0.852 \pm 0.003$ & $1.999 \pm 0.002$ & $98 \cdot 9$ \\
\hline \multirow[t]{2}{*}{$\begin{array}{l}0 \cdot 5 \\
1 \cdot 0 \\
2 \cdot 0 \\
5 \cdot 0\end{array}$} & $\begin{array}{l}\text { Urine } \\
100.0 \\
100.0 \\
100.0 \\
500.0\end{array}$ & $\begin{array}{l}1.0 \\
1.0 \\
0.5 \\
0.5 \\
\end{array}$ & $\begin{array}{l}0.723 \pm 0.002 \\
0.719 \pm 0.003 \\
0.722 \pm 0.002 \\
0.721 \pm 0.001 \\
\end{array}$ & $\begin{array}{l}1.879 \pm 0.004 \\
1.861 \pm 0.005 \\
1.864 \pm 0.008 \\
1.866 \pm 0.012\end{array}$ & $\begin{array}{l}99 \cdot 6 \\
98 \cdot 4 \\
98 \cdot 6 \\
98 \cdot 6\end{array}$ & $\begin{array}{l}2.075 \pm 0.003 \\
2.082 \pm 0.007 \\
2.087 \pm 0.005 \\
2.088 \pm 0.013 \\
\end{array}$ & $\begin{array}{l}3 \cdot 258 \pm 0.011 \\
3 \cdot 254 \pm 0.011 \\
3 \cdot 270 \pm 0.007 \\
3 \cdot 251=0.008 \\
\end{array}$ & $\begin{array}{l}101 \cdot 8 \\
100 \cdot 9 \\
101 \cdot 8 \\
100 \cdot 2\end{array}$ \\
\hline & \multicolumn{2}{|c|}{ Overall means } & $0.721=0.001$ & $1.868 \pm 0.004$ & $98 \cdot 2$ & $2 \cdot 083 \div 0 \cdot 003$ & $3 \cdot 258 \div 0 \cdot 004$ & $101 \cdot 2$ \\
\hline
\end{tabular}


TABLE III

ESTIMATION OF URINE NITROGEN AND RECOVERY OF NITROGEN ADDED TO URINE

\begin{tabular}{|c|c|c|c|c|c|c|}
\hline \multirow{3}{*}{$\begin{array}{c}\text { Quantities } \\
\text { Taken }\end{array}$} & \multicolumn{3}{|c|}{$\operatorname{Dog} 1$} & \multicolumn{3}{|c|}{$\operatorname{Dog} 2$} \\
\hline & \multirow{2}{*}{$\begin{array}{c}\text { Urine Alone } \\
\begin{array}{c}\text { Nitrogen } \\
(\%)\end{array}\end{array}$} & \multicolumn{2}{|c|}{ Urine + Urea $=1 \cdot 16 \%$ Added Nitrogen } & \multirow{2}{*}{$\frac{\text { Urine Alone }}{\substack{\text { Nitrogen } \\
(\%)}}$} & \multicolumn{2}{|c|}{ Urine + Urea $=1 \cdot 16 \%$ Added Nitrogen } \\
\hline & & $\underset{\text { Notal }}{\text { Nitrogen (\%) }}$ & $\begin{array}{l}\text { Added Nitrogen } \\
\text { (\% Recovery) }\end{array}$ & & $\underset{(N i t r o g e n}{\text { Total }} \%)$ & $\begin{array}{c}\text { Added Nitrogen } \\
\text { (\% Recovery) }\end{array}$ \\
\hline $\begin{array}{l}0.5 \mathrm{ml} . \overrightarrow{100} \mathrm{ml} . \\
1.0 \mathrm{ml} . \text { for titration } \\
\text { Mean } \pm \text { S.E. }\end{array}$ & $\begin{array}{l}0.722 \\
0.721 \\
0.719 \\
0.728 \\
0.723 \pm 0.002\end{array}$ & $\begin{array}{l}1.874 \\
1.876 \\
1.892 \\
1.874 \\
1.879 \pm 0.004\end{array}$ & $\begin{array}{l}99 \cdot 3 \\
99 \cdot 5 \\
101 \cdot 2 \\
98 \cdot 8 \\
99 \cdot 6 \pm 0 \cdot 22\end{array}$ & $\begin{array}{l}2 \cdot 076 \\
2 \cdot 070 \\
2 \cdot 080 \\
2 \cdot 068 \\
2 \cdot 075 \pm 0 \cdot 003\end{array}$ & $\begin{array}{l}3 \cdot 268 \\
3 \cdot 244 \\
3 \cdot 284 \\
3 \cdot 236 \\
3 \cdot 258 \pm 0 \cdot 011\end{array}$ & $\begin{array}{l}102 \cdot 5 \\
101 \cdot 1 \\
103 \cdot 7 \\
100 \cdot 6 \\
101 \cdot 8 \pm 0 \cdot 29\end{array}$ \\
\hline $\begin{array}{l}1.0 \mathrm{ml} . \rightarrow 100 \mathrm{ml} . \\
1.0 \mathrm{ml} . \text { for titration } \\
\text { Mean } \pm \text { S.E. } \ldots\end{array}$ & $\begin{array}{l}0.722 \\
0.721 \\
0.711 \\
0.723 \\
0.719 \pm 0.003\end{array}$ & $\begin{array}{l}1.864 \\
1.870 \\
1.860 \\
1.848 \\
1.861 \pm 0.005\end{array}$ & $\begin{array}{l}98 \cdot 4 \\
99 \cdot 1 \\
99 \cdot 1 \\
97 \cdot 0 \\
98 \cdot 4 \pm 0 \cdot 20\end{array}$ & $\begin{array}{l}2 \cdot 088 \\
2 \cdot 062 \\
2 \cdot 086 \\
2 \cdot 090 \\
2 \cdot 082 \pm 0 \cdot 007\end{array}$ & $\begin{array}{l}3 \cdot 264 \\
3 \cdot 280 \\
3 \cdot 236 \\
3 \cdot 236 \\
3 \cdot 254 \pm 0 \cdot 011\end{array}$ & $\begin{array}{l}101 \cdot 2 \\
104 \cdot 9 \\
99 \cdot 1 \\
98 \cdot 8 \\
100 \cdot 9 \pm 1 \cdot 55\end{array}$ \\
\hline $\begin{array}{l}2.0 \mathrm{ml} . \rightarrow 100 \mathrm{ml} . \\
0.5 \mathrm{ml} . \text { for titration } \\
\text { Mean } \pm \text { S.E. . }\end{array}$ & $\begin{array}{l}0.724 \\
0.720 \\
0.721 \\
0.726 \\
0.722 \pm 0.002\end{array}$ & $\begin{array}{l}1.870 \\
1.882 \\
1.842 \\
1.862 \\
1.864 \pm 0.008\end{array}$ & $\begin{array}{l}98 \cdot 8 \\
100 \cdot 1 \\
96 \cdot 7 \\
97 \cdot 9 \\
98 \cdot 6 \pm 0.08\end{array}$ & $\begin{array}{l}2 \cdot 100 \\
2 \cdot 088 \\
2 \cdot 084 \\
2 \cdot 074 \\
2 \cdot 087 \pm 0 \cdot 005\end{array}$ & $\begin{array}{l}3 \cdot 260 \\
3 \cdot 260 \\
3 \cdot 288 \\
3 \cdot 272 \\
3 \cdot 270 \pm 0 \cdot 007\end{array}$ & $\begin{array}{l}100 \\
99 \cdot 3 \\
103 \cdot 6 \\
103 \cdot 1 \\
101 \cdot 8 \pm 1 \cdot 22\end{array}$ \\
\hline $\begin{array}{l}5.0 \mathrm{ml} . \rightarrow 500 \mathrm{ml} . \\
0.5 \mathrm{ml} . \text { for titration } \\
\text { Mean } \pm \text { S.E. . }\end{array}$ & $\begin{array}{l}0.722 \\
0.722 \\
0.720 \\
0.722 \\
0.721 \pm 0.001\end{array}$ & $\begin{array}{l}1.868 \\
1.878 \\
1.832 \\
1.884 \\
1 \cdot 866 \pm 0.012\end{array}$ & $\begin{array}{c}98 \cdot 8 \\
99 \cdot 6 \\
95 \cdot 8 \\
100 \cdot 1 \\
98 \cdot 6 \pm 1 \cdot 26\end{array}$ & $\begin{array}{l}2 \cdot 061 \\
2 \cdot 100 \\
2 \cdot 073 \\
2 \cdot 075 \\
2 \cdot 088 \pm 0 \cdot 013\end{array}$ & $\begin{array}{l}3 \cdot 256 \\
3 \cdot 236 \\
3 \cdot 268 \\
3 \cdot 252 \\
3 \cdot 251 \pm 0 \cdot 008\end{array}$ & $\begin{array}{l}102 \cdot 8 \\
97 \cdot 9 \\
102 \cdot 8 \\
101 \cdot 2 \\
100 \cdot 2 \pm 1 \cdot 68\end{array}$ \\
\hline Overall mean \pm S.E... & $0.721 \pm 0.001$ & $1 \cdot 868 \pm 0.004$ & $98 \cdot 8 \pm 0.34$ & $2 \cdot 083 \pm 0.003$ & $3 \cdot 258 \pm 0 \cdot 041$ & $101 \cdot 2 \pm 0 \cdot 52$ \\
\hline
\end{tabular}

\section{Summary}

The value of the Conway microdiffusion method for a series of total nitrogen estimations is discussed.

A method using the same reagents as those required for blood urea determinations is described.

The results of estimations with urea solution, serum and urine, using varying amounts of sample, are considered.
The method is particularly useful when only small amounts of material are available, since satisfactory results may be obtained using only $0.05 \mathrm{ml}$. of sample.

I wish to thank Miss A. Facey and Miss M. Green for valuable technical assistance.

\section{REFERENCES}

Conway, E. J. (1939a). Micro-diffusion Analysis and Volumetric Error, pp. 101-105. Lockwood, London.

(1939b). Ibid. p. 10

and O'Malley, E. (1942). Biochem. J., 36, 655

Kay, W. W., and Sheehan, H. L. (1934). Ibid., 28, 1784.

Trevan, J. W. (1925). Ibid., 19, 1111 . 